Sanni, M., Oke, L.A., \& Alayande, I.T. (2020). Bank Credit Accessibility and Performance of SMEs in Kwara State, Nigeria: A PLS-SEM Analysis. Copernican Journal of Finance \& Accounting, 9(2), 45-64. http://dx.doi.org/10.12775/CJFA.2020.007

\author{
Mubaraq SANNI* \\ Kwara State University \\ Lukman Adebayo OKe ${ }^{* *}$ \\ Kwara State University \\ Idayat Titilayo Alayande ${ }^{* * *}$ \\ Kwara State University
}

\title{
BANK CREDIT ACCESSIBILITY AND PERFORMANCE OF SMES IN KWARA STATE, NIGERIA: A PLS-SEM ANALYSIS
}

Keywords: credit, performance, DMBs, SMEs, PLS-SEM.

J E L Classification: C29, E51, G21, L25.

Abstract: This study examines the effect deposit money banks credit accessibility on SMEs performance in Kwara State, Nigeria. The population of the study consists of three hundred and eighty-two (382) respondents and one hundred and ninety-eight (198) were randomly selected as the sample size of the study. Data were drawn from the primary source to elicit responses from SME owners/managers. Descriptive statis-

Date of submission: April 16, 2020; date of acceptance: June 12, 2020.

*Contact information: e-mail: dr.smubaraq@gmail.com, Department of Accounting and Finance, Kwara State University, Malete, Nigeria, phone: +2348030817202; ORCID ID: https://orcid.org/0000-0002-3609-3136.

** Contact information: okelukman2003@yahoo.com, Department of Accounting and Finance, Kwara State University, Malete, Nigeria, phone: +2348034305255; ORCID ID: https://orcid.org/0000-0003-2019-989X.

*** Contact information: alayande.idayat@gmail.com, Department of Accounting and Finance, Kwara State University, Malete, Nigeria. phone: +234830806925; ORCID ID: https://orcid.org/0000-0001-7094-0573. 
tics and Partial least square - Structural Equation Model (PLS-SEM) estimation techniques were employed to analyse the data collected. The study revealed that deposit money banks credit accessibility has a positive significant effect on SME performance ( $\mathrm{T}=10.795, \beta=0.043$ ) at $5 \%$ significance level and credit related charges (interest) also has a positive significant effect on SME performance ( $T=10.690, \beta=0.458$ ). This implies that provision of finance by deposit money banks at relatively low cost play an important role in boosting the performance of SMEs. The study therefore concluded that SMEs in Kwara State are faced with the problem of access to finance as they are not fully benefiting from the credit facilities of the deposit money banks. The study therefore recommended that deposit money banks should put in place a more SME friendly credit administration system for SMEs to enable them access fund easily and affordably.

\section{IIIITRODUCTION}

The inaccessibility of credit by SMEs has been a major hindrance to the sector in contributing meaningfully to the growth of the Nigerian economy. Unwillingness of the Deposit Money Banks (DMBs) to grant the much needed credit to the sector, likewise the attitude or the perception of the SME owners/managers about the banks' credit facility has partly been responsible for this. Globally, a lot has been said and written on the role of SMEs in the advancement of any economy. In the same token, government in Nigeria has focused on SMEs by formulating policies aimed at enhancing the performance and growth of the sector (Eniola \& Entebang, 2015; Ibrahim, 2017).

Several studies have acknowledged SMEs to have immense potentials for job and wealth creation and poverty alleviation in the less developed economies (Imafidon \& Itoya, 2014; Owolabi \& Nasiru, 2017; Bashir \& Ondigo, 2018; Erdogan, 2019). However, this goal has not been achieved in Nigeria. According to the United Nations Industrial Development Organization (UNIDO, 2012) SMEs have significant roles to play in economic development of any nation as they form the backbone of the private sector. SMEs constitute over ninety percent $(90 \%)$ of entrepreneurs of the world and account for between fifty to sixty percent (50-60\%) of employment generation and poverty alleviation (Ayuba \& Zubair, 2015).

Deposit Money Banks are known to provide channels for credit delivery through their various financial avenues. However, most of these services have not been performed to expectation due to the fact that they are characterized by cumbersome processes/stringent conditions that rarely favour the SMEs, which have contributed to the poor performance of the sector. The importance of fund/credit to a firm or business (SMEs inclusive) cannot be over- 
emphasized. The provision of funds to the SMEs and the industrial sector as a whole has been of great concern to policy makers in both the private and the public sectors (Alese \& Alimi, 2014; Ayuba \& Zubair, 2015; Ubesie, Onuaguluchi \& Mbah 2017).

Extant studies including firm-level data from the World Bank Enterprise survey over the years, reveal that financing inadequacy is a greater obstacle for SMEs than it is for large firms, particularly in the developing world, and that inaccessibility to finance constrains the growth of the SMEs sector more than that of large companies (Schiffer \& Weder, 2001; Beck, Demirguc-Kunt \& Martinez Peria, 2008). Consequently, inability of the SMEs to obtain the needed funds to pursue new businesses and finance expansion hampers their competitiveness thereby leading to their collapses in the countries world over (Kauffmann, 2006; Atieno, 2009).

The problem of access to credit by SMEs is a major issue that should be resolved considering the role of SMEs in the development of any economy. Previous studies have shown that Nigerian government have intervened in the provision and accessibility of credit to the sector by putting in place policies towards the establishment of several financial institutions and credit schemes/programmes aimed at enhancing their performance. Despite all these, SMEs are still faced with numerous challenges of which access to credit constitute a major constrain. Credit when granted are mostly on short term bases and usually too small (insufficient) to cover their working capital requirements talk more of expansion or diversification into new innovative areas.

In addition, the cost incurred on bank credit poses an insurmountable barrier to SMEs to acquire credit from DMBs in terms of excessive interest rate and other charges attached to these facilities. Considering the important role played by SMEs in the advancement of an economy, as supported by previous studies (Dalhat \& Hassan, 2016; Ubesie et al., 2017; Owolabi \& Nasiru, 2017; Bashir \& Ondigo, 2018) easy access to finance by SMEs is one of the strategies to be used in order to achieve the desired goals of job/wealth creation and the alleviation of poverty in an economy, a lasting solution need be provided to resolve these issues in order to enhance the performance of the sector which will also reflect positively on Nigeria economy. This study becomes imperative because banks in Nigeria need to understand how to impact on SMEs performance through credit accessibility. Hence, this study is undertaken to examine the effect of DMBs credit accessibility and credit related charges (interest) on SMEs performance in Kwara State, Nigeria. 
In view of the study objectives, the following hypotheses stated in null forms were formulated and tested empirically in the study.

Ho $_{1}$ : Access to DMBs credit has no significant effect on SMEs performance in Kwara State.

$\mathbf{H o}_{2}:$ Credit related charges of DMBs have no significant effect on SMEs performance in Kwara State.

\section{LITERATURE REVIEW}

Lending is one of the most important functions undertaken by DMBs in Nigeria. Banks play their intermediation role by sourcing funds through deposits from their numerous customers and such funds are given out as loan either on short, medium or long term basis to government, corporate bodies, institutions and individuals to enable them embark on viable investment ventures. Based on the fact that their operations/ business are usually pivoted around the practice of lending hence the use of expertise and competent hands by the banks' management team in carrying out their business (Ayuba \& Zubair, 2015; Ubesie et al., 2017).

It is worthy to note that small and medium scale enterprises (SMEs) have no generally established definition. However, SMEs are businesses that are privately owned and managed with a small number of employees. Kadiri (2012) asserted that the criterion for categorization of SMEs into small, medium or large scale varies from one country to another based on whether the country is developed or developing.

Small and Medium Enterprises Development Agency of Nigeria (SMEDAN) (2015) defines Small Enterprise as one which total assets (excluding land and building) is more than 10 million naira but less than 100 million naira with total workforce of more than 10 employees but less than 50 . Whereas a firm with total workforce of 50 and 199 employees with total assets (excluding land and building) of more than 100 million but not exceeding 1 billion is categorized as a medium enterprise.

Measuring business performance is an essential element in ensuring a firm's growth and survival, likewise identifying its strengths and weakness (Bandar, 2016). Performance refers to ability of an organization to achieve high profit, quality product, large market share, good financial results and survival at 
a pre-determined time (Zhiri, 2017). Apolot (2012) viewed performance in relation to sales growth, customer satisfaction and profitability. However, a large number of studies measure performance with efficiency and financial result. Hence, SME performance can be measured using either financial or non-financial assets.

SMEs in Nigeria have not performed to expectation in terms of meaningful contribution to the nation's gross domestic product (GDP). Gbandi and Amissah (2014) asserted that SMEs in Nigeria have underperformed in spite of the fact that they constitute more than ninety percent of Nigerian businesses, their contribution to GDP is below expectation contributing only about one percent to GDP. However, SMEs low performance in Nigeria has be attributed amongst others to lack of access to the much needed fund, unfriendly business environment, lack of access to modern technology and poor management skills (Akabueze, 2017).

Employing co-integration and error correction model techniques, Imoughele and Ismaila (2014) evaluated the impact of commercial bank credit on the growth of SMEs in Nigeria from 1986 to 2012. The results of the study revealed that SMEs and selected macroeconomic variables have a long run relationship with SMEs output, time deposit and exchange rate have significant impact on SMEs output while commercial bank credit to SMEs, government expenditure and bank density has direct but insignificant impact on SMEs output and interest rate has adverse effect on SMEs output.

Analyzing data collected from primary data source through the use of questionnaire, Oluitan (2014) evaluated the Impact of Commercial Bank Funding on Small and Medium Scale Enterprises in Nigeria. The findings of the study revealed that commercial bank funding for SMEs is important to enhance their activities, but currently not improving their profitability.

Acknowledging the importance of easy credit access to boosting SMEs performance, Ayuba and Zubairu (2015) evaluated the impact of banking sector credit on the growth of SMEs in Nigeria between 1985 and 2010. Correlation matrix and error correction model were used to analyse data collected and the study revealed that banking sector credit has a significant impact on SMEs growth in Nigeria with a positive impact on some major macro-economic variables. The study recommended that stringent conditions associated with credits process to SMEs should be relaxed.

Consequently, Oke and Aluko (2015) examined the Impact of Commercial Banks on Small and Medium Enterprises Financing in Nigeria between 2002 
and 2012. Using panel data regression analysis, the results of the study revealed that commercial bank credit has significant impact on SME financing hence they are capable of making SMEs grow.

In a study conducted by Kavitha Vani (2015), employing both descriptive and inferential statistical methods, findings revealed that there is high financial exclusion of the SME sector from formal financial sources, but this is due to the wrong perception of each sector on one another. Similarly, Li (2016) conducted a study on the sources of finance and the difficulties in raising finance for SMEs in China. The study revealed that personal finance; funds from families and friends along with credit from the financial industry are being widely used by SMEs in China now and the chances that the sector will access more funds from the banking system in the future. The study also revealed that venture capital financing is also available in China but due to the risk involved and the high rate of interest charged on the funds, SMEs in China has been discouraged from patronize venture capital financing.

Employing correlation and analysis of variance (ANOVA), Bandar (2016) examined financial access constraints and the impact on performance of SMEs in Saudi Arabia. The results revealed that some factors ranging from firm specific to macroeconomic impeded SMEs access to finance from the banks and prevent them from developing their businesses. The study recommended that in order to promote easy access to finance from banks to the sector there is need to establish a trusting relationship between the sector and the banks.

Employing multiple regression analysis and univariate analysis technique to analyse data collected from both secondary and primary sources, Dalhat and Hassan (2016) evaluated the role of money deposit banks in financing SMEs in Nigeria. The study revealed that financial support, business environment and managerial skills have positive impact on the growth and survival of SMEs.

Ubesie et al. (2017) examined the effect of deposit money banks' credit on SMEs growth in Nigeria between 1986 and 2015. Data from secondary source were analysed using ordinary least square (OLS) regression method and the study revealed that deposit money banks' credit has no significant effect on SMEs growth in Nigeria, while interest rate has negative but significant effect on SMEs growth in Nigeria.

Employing paired sample t-test and ratio analysis, Ibrahim (2017) evaluated the role of commercial banks in financing SMEs in Nigeria. Findings of the study revealed that commercial banks loans with the equity scheme have not positively impacted on SMEs finance. In view of this, the study called for the 
need for Nigerian commercial banks to embrace risk-averse behaviour in respect of loans to SMEs; interest rate should be review for SMEs loans and CBN should increase SMEEIS contribution by commercial banks.

Aguwamba and Ekienabor (2017) also examined the linkage between bank lending and growth of Small Scale Enterprises in Nigeria. The study employed ordinary Least Squares (OLS) regression technique to analyse data collected from 1995 to 2012. The result revealed a positive impact of bank lending on small-scale enterprises growth.

Chepsang, Iraya and Okiro (2018) evaluated the effects of access to credit on financial performance of SMEs in Nairobi County Kenya from 2012 to 2016. The study revealed a strong and positive relationship between the access to credit and SMEs performance. Adelekan, Eze and Majekodunmi (2019) also reported similar findings in Nigerian context using correlation analysis.

Extant literature reviewed on the effect of deposit money banks credit access on SMEs performance revealed mixed findings. Some evidences (Dalhat \& Hassan, 2016; Abosede, Hassan \& Oko-Oza, 2017; Bashir \& Ondigo, 2018) revealed a positive relationship others such as Oluitan (2014), Imafidon and Itoya (2014), Ubesie et al. (2017), Owolabi and Nasiru (2017) revealed a negative relationship, hence the need for further research.

In addition, most of the previous studies in this study area were conducted outside Kwara domain of Nigeria and majorly focused on microfinance banks. Notable among these studies are Owenvbiugie and Igbinnedion (2015), Abosede et al., (2017), Zhiri (2017), Akingunola, Olowofela and Yunusa (2018) and Adeoti, Gbadeyan and Olawale (2015). This study extends the knowledge frontier by focusing on DMBs in Kwara State, Nigeria. Methodologically, most of the literature reviewed used ANOVA, Chi square and OLS regression analysis as well as simple percentage and trend analysis. This study used Partial Least Square-Structural Equation Model to analyse the effect of DMBs' credit accessibility on SMEs' performance.

\section{THEORETICAL FRAMEWORK}

The connection that exists between finance and economic growth was first reported by Schumpeter (1911) and this has been contented in both the developed and developing countries. He asserted that a well functioning financial sector is necessary to induce growth in the real sector which consequently 
leads to economic growth. The finance led growth theory holds that activities of the financial institutions serve as a useful tool for increasing the productive capacity of the economy. The theory contends that nations with betterdeveloped financial system have the tendency to grow faster. The significance of credit institutions in creating development within the economy has been broadly discussed in various literatures. Schumpeter (1911) also recognized banks' role in encouraging technological development through their mediatory role such as supply of loans to the productive sector. He posits that efficient allocation of savings through recognition and funding of businessmen with the best chances of successfully applying innovative products and production processes are devices to attaining sustainable economic performance. Several researchers thereafter (McKinnon, 1973; Shaw, 1973; Fry, 1988; King \& Levine, 1993) have upheld the above hypothesis about the significance of banks to the advancement of the economy.

\section{THE RESEARCH METHODOLOGY AND THE COURSE OF THE RESEARCH PROCESS}

Cross sectional survey design was adopted in the study. This design is usually adopted when there is no intent of controlling any of the study samples (Asika, 2006).

The population of the study comprises of all 382 SMEs registered with the Kwara State Chambers of Commerce, Industry, Mines and Agriculture (KWACCIMA). The nature of the study does not allow for inclusion of unregistered SMEs in the population. KWACCIMA members were chosen because they have duly registered their businesses and operate within the standard set by SMEDAN for SMEs. And registration of business is also one of the prerequisite for obtaining credit from Deposit Money Banks. A sample size of 198 SMEs was selected based on Yamane (1967) using stratified sampling technique. (See Appendix 1).

The source of data collection for the study was obtained through questionnaire administered to the target respondents. The questionnaire was divided into two (2) parts, sections A and B. Section A contains the social demographic information about the respondents, while section $B$ focused on the research objectives and the hypotheses stated. The questionnaire of Kavitha Vani (2015) and Bandar (2016) were adapted and modified to suit the objective of the study. 
Also, validity and reliability tests were conducted to substantiate the instruments used for data collection. Descriptive and inferential statistics were used for data analysis. The descriptive statistics employed includes mean, frequency and standard deviation to explain the demographic data while Partial Least Square-Structural Equation Model (PLS-SEM) was used to achieve the research objectives stated as well as testing the hypotheses formulated.

\section{MODEL SPECIFICATION}

The econometric model employed in this study to evaluate the effect of Deposit Money Banks credit accessibility on SMEs performance in Kwara State was adapted with modification from the previous empirical study of Ubesie et al. (2017) as follows:

$$
S M E P=f(A B C, C R C)
$$

This can be specified in operational form as:

$$
\operatorname{SME}(\mathrm{P})_{\mathrm{i}}=\beta_{0}+\beta_{1} \mathrm{ABC}_{\mathrm{i}}+\beta_{2} \mathrm{CRC}_{\mathrm{i}}+\mu_{\mathrm{i}}
$$

Where:

$\operatorname{SME}(\mathrm{P})_{\mathrm{i}}=$ Small and Medium scale enterprises performance

$\beta_{0}=$ Constant Coefficient

$\beta_{1} . \beta_{2}=$ Slope or regression parameters

$\mathrm{ABC}=$ Access to Bank credit

$\mathrm{CRC}=$ Credit related charges

$\mu=$ Stochastic error term

${ }^{\mathrm{i}}=$ Cross sectional (individual) 


\section{RESULTS AND DISCUSSIONS}

\section{Demographic profile of respondents}

The demographic profiles of respondents were summarized in table 1:

Table 1. Demographic Profile of Respondents

\begin{tabular}{|l|l|c|c|}
\hline \hline \multicolumn{1}{|c|}{ Variable } & & Frequency & Percentages \\
\hline \hline Gender & Male & 95 & 47.98 \\
& Female & 103 & 52.02 \\
\hline \multirow{2}{*}{ Nature of Business } & Small Enterprises & 147 & 74.24 \\
& Medium Enterprises & 51 & 25.76 \\
\hline \multirow{2}{*}{ Qualification } & Ph.D. & 6 & 3.03 \\
& Masters & 21 & 10.61 \\
& B.sc. & 39 & 19.69 \\
& H.N.D. & 58 & 29.29 \\
& Others & 74 & 37.37 \\
\hline \multirow{2}{*}{ Position } & Owner & 144 & 72.73 \\
& Manager & 54 & 27.27 \\
\hline \multirow{2}{*}{ Years of Existence } & O-5 & 11 & 5.6 \\
& 6-10 & 82 & 41.4 \\
& $11-15$ & 61 & 30.8 \\
& 16 and above & 44 & 22.2 \\
\hline \hline
\end{tabular}

S o u r c e : authors' computation, 2019.

Regarding respondents' gender, significant portion of the respondents were female numbering 103 (52.02\%), while the male were 95 constituting (47.98\%). This implies that more female gender owns/manages SMEs operations in Kwara State. As for the nature of business, the small enterprises have a sampled populace of 147 (74.24\%) while the medium enterprises have 51 (25.76\%). This implies that there are more respondents from small businesses than the medium businesses in Kwara State. Regarding educational qualifications, 6 respondents (3.03\%) are Ph.D. holders, 21 respondents (10.61\%) have M.Sc., while 39 respondents (19.69\%) are B.Sc. holders. Also, 58 respondents (29.29\%) have HND and majority of the respondents (74) representing $37.37 \%$ have other qualifications not included in the options. This is an indication that most of the SMEowners/managers in the study area are literate and are able to comprehend the 
instrument administered. The table also shows that most of the respondents are business owners representing $72.24 \%$ and they have requisite experience spanning 6 to 10 years on the average.

\section{Normality test}

Normality test was carried out on the basis of individual items measuring the constructs in the study. The study utilized skewness and kurtosis statistics to assess the normality. Critical value of +2.58 (.01 sig level) and +1.96 (@.05 sig level) are benchmark. The result of this test showed that all items are relatively normal as shown in figure1 below:

Figure 1. Normal probability plot

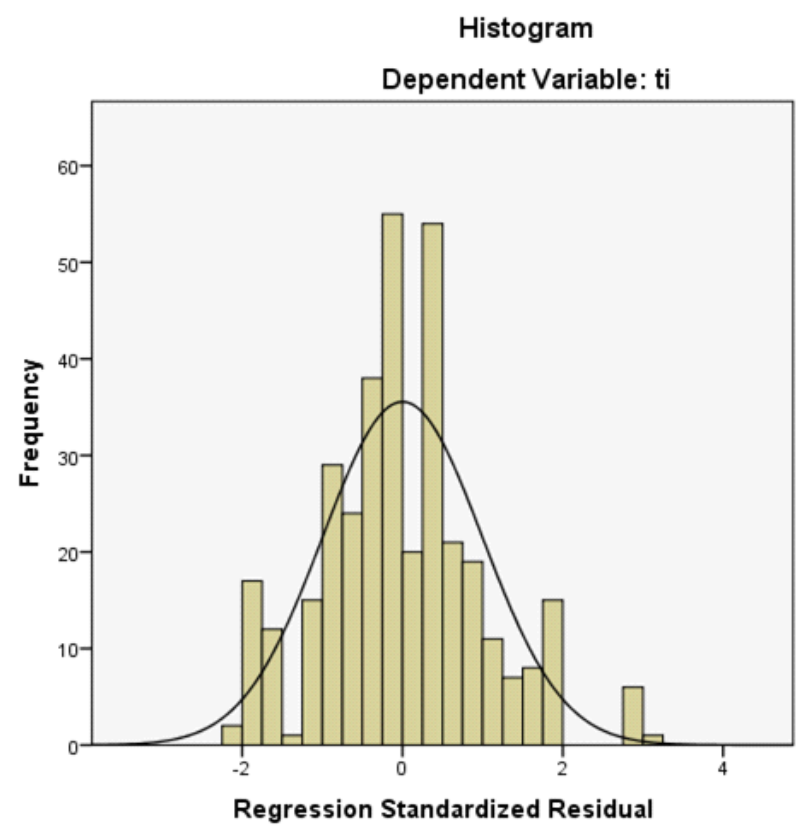

S o u r c e : authors' computation, 2019. 
Table 2. Construct Reliability and Validity

\begin{tabular}{|c|c|c|c|}
\hline \hline & Access to Credit & Interest Rate & SMEs Performance \\
\hline \hline A.C1 & 0.771864 & & \\
\hline A.C2 & 0.779573 & & \\
\hline A.C3 & 0.727216 & & \\
\hline A.C4 & 0.764385 & & \\
\hline C.R1 & & 0.778904 & \\
\hline C.R2 & & 0.725679 & \\
\hline C.R3 & & 0.822812 & 0.755584 \\
\hline C.R4 & & 0.763748 & 0.806723 \\
\hline SMEs1 & & & 0.782878 \\
\hline SMEs2 & & & 0.813255 \\
\hline SMEs3 & & & \\
\hline SMEs4 & & & \\
\hline \hline
\end{tabular}

S o u r c e : authors' computation (2019) using SmartPls2.

Table 2 depicts how well items measuring each of the study variables loaded to determine their retention or otherwise. On the table, items measuring access to credit, credit related charges (interest rate) and SMEs performance loaded well, as they loaded above 0.7 hence, all items were retained and used to measure the study variables.

Table 3. Construct Overview of the Model

\begin{tabular}{|l|c|c|c|}
\hline \hline & AVE & Composite Reliability & Cronbachs Alpha \\
\hline \hline Access to Credit & 0.579159 & 0.846176 & 0.758255 \\
\hline Interest Rate & 0.598408 & 0.856080 & 0.775749 \\
\hline SMEs Performance & 0.623998 & 0.868986 & 0.799465 \\
\hline \hline
\end{tabular}

S o u r c e : authors' computation (2019) using SmartPls2. 
Likewise, as depicted by table 3 , all construct met the minimum benchmark for both composite reliability and AVE which is 0.7 and 0.5 respectively. The Cronbachs Alpha statistics for all the variables are above 0.7 indicating internal consistency among the statements measuring each of the constructs.

Table 4. Fornell-larcker Discriminant Validity Test

\begin{tabular}{|l|c|c|c|}
\hline \hline & Access to Credit & Interest Rate & SMEs Performance \\
\hline \hline Access to Credit & 0.761025 & & \\
\hline Interest Rate & 0.565012 & 0.773568 & \\
\hline SMEs Performance & 0.689090 & 0.701083 & 0.789935 \\
\hline \hline
\end{tabular}

S o u r c e : authors computation (2019) using SmartPls2.

Table 4 shows the discriminant validity result. The square root of AVE in each latent variable was used to establish discriminant validity; if this value is larger than other correlation values among the latent variables then discriminant validity is well established (Fornell \& Larcker, 1981). This number is larger than the correlation values in the column and row, thus result indicates that discriminant validity is well established.

Table 5. Path Coefficients and Hypotheses Testing

\begin{tabular}{|l|c|c|c|c|c|}
\hline \hline \multicolumn{1}{|c|}{ Hypotheses (Adj. $\left.\mathbf{R}^{\mathbf{0}} \mathbf{0 . 6 1 8}\right)$} & B Value & Standard Error & T Statistics & P Value & Decision \\
\hline \hline $\begin{array}{l}\text { Access to Credit -> SMEs } \\
\text { Performance }\end{array}$ & 0.430356 & 0.039866 & 10.795074 & $0.000^{* * *}$ & Rejected \\
\hline $\begin{array}{l}\text { Credit Related Charges } \\
\text { (interest rate) -> SMEs } \\
\text { Performance }\end{array}$ & 0.457927 & 0.042837 & 10.689924 & $0.000^{* * *}$ & Rejected \\
\hline \hline
\end{tabular}

value $^{* * *}<0.01, \mathrm{P}$ value $\mathrm{e}^{* *}<0.05, \mathrm{P}$ value $\mathrm{e}^{*}<0.10$.

S o u r c e : authors computation (2019) using SmartPls2.

The result in table 5 shows the relationship between DMBs credit access and SMEs performance. The $\mathrm{R}^{2}$ value represents the proportion of variation in the dependent variable that can be explained by one or more predictor variables. 
As indicated in Figure 2, adjusted $\mathrm{R}$ square is 0.618 , implying that $61.8 \%$ variance in SMEs performance is accounted for by access to DMBs credit and DMBs credit related charges, while $38.2 \%$ is accounted for by other variables that can equally influence SMEs performance that were not captured in this study.

Figure 2. Construct Reliability and Validity



S o u r c e : authors' computation (2019) using SmartPls2.

As shown in table 5 above, access to credit has a positive significant effect on SMEs performance as indicated by $(t=10.795$, p-value 0.000$)$ at 0.05 level of significance with a beta value of 0.430 , thereby providing a basis to reject the null hypothesis which stated that access to DMBs credit has no significant effect on SMEs performance in Kwara State and accepting the alternative hypothesis. Hence, a unit change in access to DMBs' credit will lead to 0.430 unit change in SMEs performance. This result implies that access to credit play an important role in boosting the performance of SMEs in Kwara State. 
Figure 3. Model of Deposit Money Banks' credit accessibility and performance of SMEs

Bootstrapping

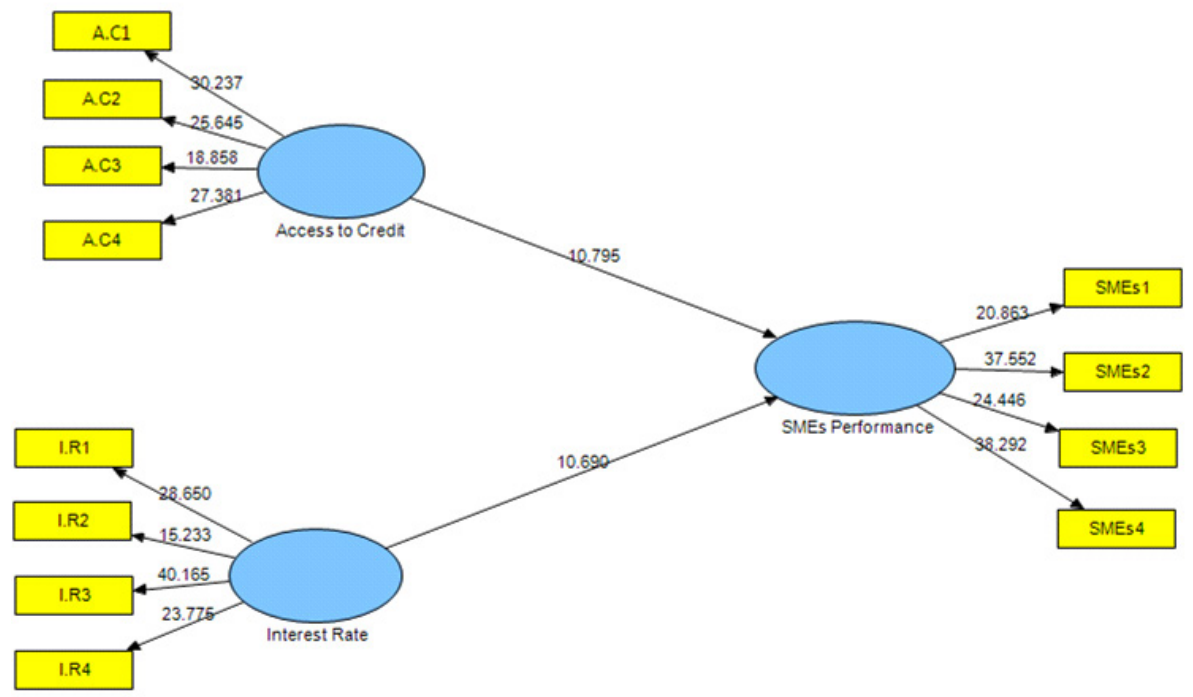

S o u r c e : authors' computation (2019).

As revealed in table 5 above, it can be deduced that credit related charges of DMBs has a positive significant effect on SMEs performance in Kwara State $(t=10.690$, p-value 0.000$)$ at 0.05 level of significance with a beta value of 0.458 . Thus, the null hypothesis which stated that credit related charges of DMBs' have no significant effect on SMEs performance in Kwara State is hereby rejected while the alternative hypothesis is accepted. This implies that a unit change in credit related charges of DMBs' will lead to 0.458 unit increase in SMEs performance in Kwara State. 


\section{DISCUSSION OF FINDINGS}

From the empirical analysis and hypotheses tested about, the results revealed that the independent variable proxy with access to bank credit and credit related charges exact significant positive effect on SMEs performance.

The study found that access to deposit money banks credit has a significant positive effect on SMEs performance in Kwara State. This is in line with the prediction of the finance led growth theory that a well functional financial sector is necessary to induce growth in the real sector. This implies that the activities of the DMBs play an essential role in attaining sustainable performance of the SME sector. Hence easy access to credit that can be used for expansion and diversification purposes will absolutely go a long way to enhance the performance of the sector. The result support the a-priori expectation and the findings of the study corroborates with the study of Oluitan (2014), Ayuba and Zubairu (2015), Dalhat and Hassan (2016) and Abosede et al. (2017) where they found significant positive relationship between access to credit and SMEs performance. However, Imafidon and Itoya (2014), Ubesie et al. (2017), Owolabi and Nasiru (2017) and Ibrahim (2017) reported negative significant relationship between access to credit and the performance of SMEs. This might be due to geographical, population and sample size or construct of the study peculiarities.

The study also revealed that credit related charges have significant positive effect on SMEs performance in Kwara State. The implication of this is that the charging of relatively prohibitive interest rate to SMEs by the DMBs, given the presence of information asymmetry, puts them on their toes to perform and repay both the principal sum and interest. The result is however in consistence with the study of Anigbogu, Okoli and Nwakoby (2015) and Tumwine, Akinsimire, Kamukama and Mutaremwa (2015) who also reported similar findings but contrasts that of Ubesie et al. (2017) that reported a negative significant effect of interest on SMEs performance.

\section{CONCLUSION AND RECOMMENDATIONS}

Based on the result of the hypotheses tested above, the study concluded that DMBs credit accessibility have significant positive effect on SMEs performance in Kwara State. This implies that difficulties in accessing finance are signifi- 
cantly related to the performance of SMEs. Therefore, easy access to credit at relatively low cost would enhance the performance of the sector to contribute tremendously to the growth and development of the economy.

Based on the findings that DMBs credit accessibility has significant positive effect on SMEs performance, it is recommended that the monetary authorities should review policies that will improve credit access to the sector while the DMBs should put in place standardized credit administration system in order to ensure easy access to funds by the sector. Also, in view of the findings that credit related charges (interest charges) spur SMEs to perform, it is recommended that DMBs should open more SME friendly financial windows at relatively lower interest for the generation of more economic activities and provide compensating incentives for the interest charges.

\section{REFERENCES}

Abosede, A.J., Hassan, B.A., \& Oko-Oza, R.O. (2017). Performance of small and medium scale enterprises in Lagos state: The Implication of finance. Journal of Research in National Development, 15(1), 271-277.

Adelekan, A.S., Eze, B.U., \& Majekodunmi, S.A. (2019). The link between bank loan and Small and Medium Enterprise (SME) performance in Lagos, Nigeria. Ilorin Journal of Human Resource Management, 3(1), 52-61.

Adeoti, G.O., Gbadeyan, R.A., \& Olawale, Y.A. (2015). The impact of micro-finance institutions credit on the survival of small and medium scale enterprises in Irepodun LGA of Kwara State, Nigeria. Pacific Journal of Science And Technology, 16(2), 180-188.

Aguwamba, S., \& Ekienabor, E. (2017). Bank Lending and its Impact on Small Scale Enter prises in Nigeria. Imperial Journal of Interdisciplinary Research, 3(3), 58-66.

Akabueze, M. (2017). Poverty in Nigeria: Characteristics, alleviation strategies and programmes. NCEMA Policy Analysis Series, 2(2), 11-32.

Akingunola, R.O., Olowofela, E.O., \& Yunusa, L. (2018). Impact of microfinance banks on micro and small scale enterprises in Ogun state, Nigeria. Binus Business Review, 9(2), 163-169. https://dx.doi.org/10.21512/bbr.v9i2.4253.

Alese, J., \& Alimi, O.Y. (2014). Small and medium-scale enterprises financing and economic growth in Nigeria: Error correction mechanism, European Journal of Globalization and Development Research, 11(1), 639-652.

Anigbogu, T.U., Okoli, I.M., \& Nwakoby, N.P. (2015). Financial intermediation and small and medium enterprises performance in Nigeria (An aggregated analysis: 19802013). European Scientific Journal, 11(28), 257-272.

Apolot, S. (2012). Organizational learning, innovation and small and medium enterprise (SMEs) performance in Uganda. M.Sc. Dissertation. Kampala, Uganda: Makerere University. 
Asika, N. (2006). Research Methodology in Behavioural Sciences. Lagos: LONGMAN Nigeria Plc.

Atieno, R. (2001). Formal and informal institutions' lending policies and access to credit by small-scale enterprises in Kenya: An empirical assessment. African Economic Research Consortium, 2(3), 22-35.

Ayuba, B., \& Zubairu M. (2015). Impact of Banking Sector Credit on the Growth of Small and Medium Enterprises (SME's) in Nigeria. Journal of Resources Development and Management, 15, 1-9.

Bandar, W. (2016). Access to finance by Saudi SMEs: Constraints and the impact on their performance. Ph.D. thesis. Melbourne, Australia: Victoria University.

Bashir, A.B., \& Ondigo, H.O. (2018). Effect of financial product on performance of small and medium enterprises in Niarobi county. Journal of International Business, Innovation and Strategic Management, 1(6), 1-36.

Beck, T., Demirguc-Kunt, A., \& Martinez Peria, M. (2008). Bank financing for SMEs around the world: Drivers, obstacles, business models, and lending practices. Policy Research Working Paper, 4785, Washington DC: World Bank.

Dalhat, B.S., \& Hassan, N.M. (2016). Role of money deposit banks in financing small and medium scale enterprises (SMEs) in Nigeria. Proceedings of ISER 27th International conference, Riyadh, Saudi Arabia.

Eniola, A.A., \& Entebang, H. (2015). SME firm performance-financial innovation and challenges. Procedia - Social and Behavioral Sciences, 195, 334-342. https://dx.doi. org/10.1016/j.sbspro.2015.06.361.

Erdogan, A.I. (2019). Determinants of perceived bank financing accessibility for SMEs: evidence from an emerging market. Economic Research-Ekonomska Istraživanja, 32(1), 690-716. https://dx.doi.org/10.1080/1331677X.2019.1578678.

Fornell, C., \& Larcker, D.F. (1981). Evaluating Structural Equation Models with Unobservable Variables and Measurement Error. Journal of Marketing Research, 28(1), 3950. https://dx.doi.org/10.1177/002224378101800104.

Fry, M.J. (1988). Money, interest and banking in economic development. Baltimore MD: Johns Hopkins University Press. https://dx.doi.org/10.2307/1242046.

Gbandi, E.C., \& Amissah, G. (2014). Financing options for small and medium enterprises (SMEs) in Nigeria. European Scientific Journal, 10(1).

Ibrahim, A.G. (2017). An evaluation of the role of commercial banks in financing small and medium scale enterprises (SMEs): evidence from Nigeria. Indian Journal of Finance and Banking, 1(1), 16-32. https://dx.doi.org/10.46281/ijfb.v1i1.82.

Imafidon, K., \& Itoya, J. (2014). An analysis of the contribution of commercial banks to small scale enterprises on the growth of the Nigeria economy. International Journal of Business and Social Science, 5, 9(1), 256-263.

Imoughele, L.E., \& Ismaila, M. (2014). Commercial bank credit accessibility and sectoral output performance in a deregulated financial market economy: empirical evidence from Nigeria. Journal of Finance and Bank Management, 1(2), 36-59. 
Kadiri, I.B. (2012). Small and medium scale enterprises and employment generation in Nigeria: The role of finance. Kuwait Chapter of Arabian Journal of Business and Management Review, 1(9), 79-94.

Kauffmann, C. (2006). Financing small and medium enterprises in Africa. African Technology Development Forum Journal, 3(2), 122-129.

Kavitha Vani, S.D. (2015). A study of finance gap between commercial banks and micro small and medium enterprises with reference to Karnataka. Published Ph.D. thesis. Mysore: University of Mysore.

King, R.G., \& Levine, R. (1993). Finance and growth: Schumpeter might be right. Quarterly Journal of Economics, 108(3), 717-737. https://dx.doi.org/10.2307/2118406.

Li, Z.F. (2016). Analysis on Sources of Finance and Difficulties in Raising Finance for Small and Medium sized Companies. International Journal of Business and Management, 12(3), 27-38. https://dx.doi.org/10.3968/8450.

McKinnon, R.I. (1973), Money and capital in economic development. Washington, D.C.: Brookings institutes.

Oke, M.O., \& Aluko, O.A. (2015). Impact of commercial banks on small and medium enterprises financing in Nigeria. Journal of Business and Management, 17(4), 23-26. https://dx.doi.org/10.9790/487X-17412326.

Oluitan, R. (2014). Impact of commercial bank funding on small and medium scale enterprises in Nigeria. International Journal of Financial Markets, 1(2), 62-69.

Owenvbiugie, R.O., \& Igbinedion, V.I. (2015). Role of finance on the growth of small and medium scale enterprises in Edo state of Nigeria. Journal of Educational and Social Research, 5(1), 241-247. https://dx.doi.org/10.5901/jesr.2015.v5n1p241.

Owolabi, O.A., \& Nasiru, D. (2017). Deposit money credit to small and medium scale enterprises, socioe-conomic performance and economic growth in Nigeria. International Journal of Development and Sustainability, 6(10), 1400-1417.

Schiffer, M., \& Weder, B. (2001). Firm Size and the Business Environment: Worldwide Survey Results. IFC discussion paper, 43, https://openknowledge.worldbank.org/ bitstream/handle/10986/13988/multi0page.pdf (accessed: 5.10.2018).

Schumpeter, J.A. (1911). The theory of economic development. Cambridge: Harvard University press.

Shaw, E.S. (1973). Financial deepening in economic development. London: Oxford University press.

Small and Medium Enterprises Development Agency of Nigeria (SMEDAN) (2015). National Policy on Micro, Small and Medium Enterprises, https://www.smedan.gov. ng/images/PDF/NATIONAL-POLICY-ON-MSMEsNew.pdf (accessed: 10.11.2018).

Tumwine, S., Akinsimire, R., Kamukama, N., \& Mutaremwa, G. (2015). A borrowing cost model for effective performance of small and medium enterprises in Uganda. World Journal of Entrepreneurship Management and Sustainable Development, 11(2), 74-84. https://dx.doi.org/10.1108/WJEMSD-03-2014-0009.

Ubesie, M.C., Onuaguluchi, I.F., \& Mbah, A.M. (2017). Effect of deposit money banks credit on small and medium scale enterprises growth in Nigeria. Internation- 
al Journal of Finance and Accounting, 6(5), 117-132. https://dx.doi.org/10.5923/j. ijfa.20170605.01.

Yamane, T. (1967). Statistics: An Introductory Analysis ( $2^{\text {nd }}$ ed.). New York: Harper and Row.

Zhiri, D.D. (2017). Impact of microfinance services on performance of small and medium scale enterprises (SMEs) in Zaria metropolis. International Journal of Scientific Research in Social Sciences and Management Studies, 2(1), 49-65.

\section{APPENDIX 1}

\section{Sample Size and sampling technique}

\begin{tabular}{|r|l|c|c|}
\hline \hline S/N & \multicolumn{1}{|c|}{ Sector (Stratum) } & Population & \\
\hline \hline 1 & Manufacturing & 27 & $27 / 382 * 198=14$ \\
\hline 2 & Wholesale and Retail & 89 & $21 / 382 * 198=11$ \\
\hline 3 & Accommodation and Food & 35 & $35 / 382 * 198=18$ \\
\hline 4 & Construction & 56 & $56 / 382 * 198=29$ \\
\hline 5 & Water supply & 8 & $8 / 382 * 198=4$ \\
\hline 6 & Waste Management & 11 & $11 / 382 * 198=6$ \\
\hline 7 & Transportation & 31 & $31 / 382 * 198=16$ \\
\hline 8 & Information and Communication & 48 & $48 / 382 * 198=25$ \\
\hline 9 & Agriculture & 33 & $33 / 382 * 198=17$ \\
\hline 10 & Education & 23 & $23 / 382 * 198=12$ \\
\hline 11 & Entertainment & 382 & 198 \\
\hline Total & & & \\
\hline \hline
\end{tabular}

S o u r c e : authors' compilations and computations (2019). 